\title{
Understanding Teacher Hiring Practices in Rural, Urban, Suburban Schools in the United States
}

\author{
Laurie A. Kimbrel ${ }^{1, *}$ \\ ${ }^{1}$ Dept. Leadership, Research, and School Improvement, University of West Georgia, 1601 \\ Maple Street, Carrollton, GA 30118, USA \\ *Corresponding author: Dept. Leadership, Research, and School Improvement, University of \\ West Georgia, 1601 Maple Street, Carrollton, GA 30118, USA. Tel: 1-415-578-8296. E-mail: \\ lkimbrel@westga.edu
}

Received: June 14, 2019 Accepted: July 11, 2019 Published: July 18, 2019

doi:10.5296/ije.v11i3.14925 URL: https://doi.org/10.5296/ije.v11i3.14925

\begin{abstract}
The link between student success and teacher quality has been made clear by decades of research; therefore, it is imperative that principals hire the teachers most likely to impact student outcomes positively. Hiring high-quality teachers is especially important in urban and rural schools where students are more likely to face a variety of family and community-based barriers to learning. This study was designed to examine the actual hiring processes utilized in schools located in urban, rural, and suburban communities in the USA to determine the extent to which differences exist and whether those differences are likely to impact teacher quality. Data were gathered using a survey e-mailed to principals in ten states in the southern and western regions of the United States. Analysis indicated that differences in application, hiring processes, and the criteria used for decision making exist and may result in unequal teacher quality.
\end{abstract}

Keywords: Teacher hiring; Teacher quality; Rural schools; Urban schools; Suburban schools; Structured interviews 


\section{Introduction}

There is a growing body of research that closely connects the quality of classroom teachers to student growth and learning outcomes (Ballard \& Bates, 2008; Darling-Hammond, 2000; Hattie, 2009; Marzano, 2003; Stronge, Ward, Tucker, \& Hindman, 2008). While school and home level factors do impact learning, receiving instruction from a high-quality teacher has consistently been found to outweigh even the most challenging family and community circumstances. Teachers have from two to three times the impact of any other school factor, including programming, the quality of the school leader, and access to technology (Marzano, 2003; Teachers Matter, 2012). Given the documented connection of high-quality teachers to student achievement, school improvement requires that principals hire only the teachers most likely to impact student outcomes positively. Teacher quality is especially critical in schools where a high percentage of students face significant challenges as a result of poverty, language, or other community and family barriers that can make learning more difficult. Teachers who maintain the status quo or perform poorly will not create the change that is necessary to ensure that all students learn at high levels.

Despite a large number of demands currently made on educators, it remains the primary purpose of schooling to ensure that all students learn and grow. Recent changes in local, state, and national accountability systems in the United States have refocused school leaders on student learning and have placed increased pressure on principals to document that every student receives quality instruction and learns at high levels (Troutman, 2012). To improve the odds of student success and to meet accountability demands, principals must ensure that each teacher in their school is highly trained and skilled in the use of effective instructional strategies that will increase student learning (OECD, 2004, 2005).

\subsection{The Importance of Teacher Hiring}

In response to the decades of teacher quality research, educational practitioners have made significant changes in curriculum alignment, evaluation, and professional development that have resulted in increased teacher skill (Jacob 2016; WestEd, 2000); however, personnel selection research makes it clear that an investment in a robust hiring process has a more significant impact than a similar size investment in staff training (Behrstock \& Coggshall, 2009). Critical job skills such as judgment and flexibility, take years to develop if they are not present at the time of hiring. Even in the cases where the essential skills can be more easily acquired, finding candidates who already possess these skills is more cost efficient (Wellins \& Schweyer, n.d.). Some education researchers have concluded that teacher hiring is an often overlooked, yet essential element of school improvement because of the clear link between competent teachers and high student achievement (Clement, 2009). Most principals agree that hiring qualified and capable teachers is one of their most important roles (Pillsbury, 2005) and bad hiring decisions are detrimental to both student achievement and school culture (Clement, 2009).

Hiring low-skilled teachers who are a poor fit may result in teacher turnover, which is a costly problem for both students and school districts. Students whose teachers frequently leave are likely to suffer worse learning outcomes than other students (A leak in the pipeline, 
2018). Also, the financial costs of turnover are exorbitant. Schools in the USA spend about two billion dollars of public tax money each annually on teacher turnover (Alliance for Excellence in Education, 2014).

\subsection{Teacher Hiring Challenges}

Teacher hiring is typically a decentralized process conducted at the school level by the principal, who is not likely to have human resources training (Jacob, 2016). Without a centralized hiring system, principals tend to create idiosyncratic systems (Jacob, 2016) in which they hire teachers based on their interpretation and perceptions of the candidate's competency, character and chemistry (Bourke, 2012) rather than those candidates who are a close match for the vision of the school (Mertz, 2010). Every time a principal hires a new teacher, it is an opportunity to improve the school and outcomes for students (Mertz, 2010) but making accurate predictions about the quality of a teacher during the selection process has traditionally been very difficult because "... accepted measures of teacher quality such as experience and years of schooling are only weakly linked with student achievement; they are not reliable proxies for effective teaching" (Hanushek \& Rivkin, 2007, p. 70). Also, hiring practices in schools have not evolved at the same rate as hiring practices in other industries. A nation-wide survey conducted by the Center for American Progress revealed that teacher selection processes often singularly focus on the review of application materials such as resume and transcripts rather than performance-based or predictive measures (Konoske-Graf, Partelow, \& Benner, 2016).

Similarly, a 2018 survey conducted by the Frontline Research and Learning Institute, found that only $5 \%$ of the 600 school hiring managers surveyed utilized a consistent research-based protocol to assess teacher applicants. This study also noted additional teacher quality problems created through limited recruitment efforts. Only about $15 \%$ of the total number of teacher applicants are a result of personal referrals, but these applicants accounted for a full one-third of those hired. The report concludes that the likability bias and bias towards those who are referred by colleagues can result in poor hiring decisions and eventually, high teacher turnover.

Over recent years, teacher selection research has gained some traction, and there is now a small, but growing, body of literature about elements of the teacher hiring process that are predictive of success on the job. Recent studies from Spokane, Washington, Minneapolis, Minnesota, and Washington DC have reported links between screening tools, structured interviews and teacher success (Barnum, 2017), but the bulk of this work is still in its infancy and may take many years for it to gain traction in the thousands of school districts across the USA, many of which are very small and in remote locations (Will, 2019). Despite these barriers, hiring teachers with the highest likelihood of success is a worthy pursuit in that it would likely reduce the need for time-intensive and costly remediation or in the worst case scenario, implementation teacher non-renewal processes. Based on the abundance of teacher quality research, it is also likely that the impact of teachers on student learning will increase if educational leaders utilize emerging research while designing their teacher selection systems. 


\subsection{Additional Challenges in Rural and Urban Schools}

Hiring effective teachers can be difficult for all school principals, but rural and urban principals face additional challenges based on low supplies of teachers, especially in critical areas such as science, math, and special education (Harmon, 2001). Teacher hiring is not only typically decentralized, but also highly localized, which can result in a lack of qualified applicants even for positions not usually considered to be in shortage areas. Most new teachers desire a teaching position near the community in which they grew up or minimally, in an area very similar to their hometown (Boyd, Lankford, Loeb \& Wykoff, 2003). Schools in rural communities are less likely to offer college preparation type courses because they do not have teachers with the skill to teach such courses, and therefore, rural schools tend to produce fewer college graduates. This lower pool of college graduates from which to draw exacerbates the shortage of qualified teacher candidates who are available to then return to their rural hometown to teach, thus perpetuating the cycle of small numbers of high school graduates who are prepared to attend college (Monk, 2007). Rural administrators also report that community factors such as isolation, lack of social opportunities, and lack of community-based businesses and services make it difficult to recruit qualified teachers to their areas (Luft, 1993).

The low number of teachers who apply for openings in rural schools creates conditions under which administrators often struggle to find teacher applicants who are certified to teach the subjects required, who are willing to stay in the community for more than a few years, and who are willing to accept what is usually a smaller salary and benefit package than in an urban or suburban school (Townsell, 2007). Lower salaries and challenging working conditions can necessitate the hiring of less experienced teachers, more out of field teaching assignments, larger class sizes, and in general, teachers not prepared for the realities of teaching in a rural setting (Jimerson, 2003). An additional complication to hiring effective teachers for rural schools lies in the preparation process of preservice teachers. Most colleges and universities do not prepare their pre-service teachers to understand and manage challenges of employment in a rural school. Stone (1990) found that of 306 colleges surveyed, only nine offered courses specifically focused on teaching in rural settings.

Hiring high-quality teachers can also be difficult in the urban setting where students often have less support or assistance in the home than their wealthier suburban counterparts (Jacob, 2007). According to the Schools and Staffing Survey by the National Center for Education Statistics (2006), 34.7\% of urban schools had difficulty hiring math teachers compared to only $25 \%$ in suburban schools. Urban teachers tend to be less experienced, are less likely to possess appropriate credentials, and are less likely to stay in the school for four or more years (Jacob, 2007). Like their rural counterparts, students in urban schools are more likely to live in poverty, to be English Language Learners, and to be highly mobile, thus creating significant challenges to student learning and for teachers (Jacob, 2007). Although urban school districts often receive a reasonable number of candidates for each vacancy, they face shortages because many applicants are only interested in particular schools located in the most desirable neighborhoods, leaving the most challenging schools with vastly fewer qualified candidates (Jacob, 2007). The large size of many urban districts can work against 
the hiring process. Levin and Quinn (2003) used case studies to describe four urban school districts that consistently lost high-quality candidates because of late hiring as a result of their slow-moving bureaucracy.

\subsection{Recommendations from Management and Teacher Quality Research}

Much of the new generation of teacher selection research expands upon selection science research from the field of management. Personnel selection techniques, such as the employment interview, have been extensively studied for the last century (Buckly, Norris, $\&$ Wiese, 2000). It is widely understood that because no one tool is perfect, and the traditional interview alone is quite unreliable (Buckley, Norris \& Wiese, 2000; Deli \& Vera, 2003; Hamdani, Valcea, \& Buckley, 2014; Macan, 2009), that a selection system with multiple steps should be developed and utilized. Moore (2017) identified three essential elements for an effective hiring process: (1) identification of key qualifications and prior experience necessary for success, (2) a structured interview process aligned to identified skills and abilities essential for success on the job and creation of interview questions and acceptable answers in order to assess whether the candidates possess the identified attributes, and (3) addition of other predictive elements so that decisions are not based solely on paper screening and interviews.

The first step of an effective hiring process as identified by Moore (2017) involves the identification of key qualifications and prior experience necessary for success at a particular job. Identifying such qualifications for K-12 teachers has also been the subject of research over recent years, and the body of literature indicates that traditional teacher qualifications have little influence on classroom achievement. Buddin and Zamarro (2009) found no correlation between the level of education, grade point average, and teacher licensure test scores on student achievement. Similarly, Chingos and Peterson (2011) found that neither holding a college major in education nor acquiring a master's degree is correlated with elementary and middle school teaching effectiveness, regardless of the university that granted the degree.

Given the lack of connection between teacher background characteristics and student outcomes, educators need to move beyond these types of factors to a focus on clear and consistent criteria for teacher success based on the current body of teacher quality literature. Schmid (2018) found that teachers who believed that all students could learn and that student learning was a direct reflection of their teaching practice were likely to have a higher impact on student outcomes than those who did not hold these beliefs. The same study also reported that being engaged in one's professional learning, including collaboration with colleagues and using student data to drive instruction, was a characteristic of high impact teachers. The notion of teachers who understand their impact on student learning as an indicator of success is also a strong aspect of meta-analyses conducted by Hattie \& Zierer (2018).

The traditional employment interview is the most commonly used tool for the selection of employees in industries and organizations across the United States (Crosby, 2000) and the field of education is no exception as most principals rely on interviews as their primary source of information regarding a candidate (Cannata, Rubin, Goldring, Grissom, Neumerski, Drake, \& Schuermann, 2017). Despite its popularity, the traditional interview is among the most 
unreliable elements of the selection process in any industry (Moore, 2017) and is particularly problematic in education because it offers minimal opportunities to accurately assess a teacher's pedagogical skills (Engel, 2013). The validity and reliability of the interview process can be significantly improved when there is a reduction of bias and inconsistency, which can be accomplished through the addition of elements of structure (Moore, 2017). Through the meta-analysis of a decade of research, Lavashina, Hartwell, Morgeson, \& Campion (2014) found six essential elements of structured interviews:

- job analysis used to create questions;

- identical questions asked of each candidate;

- variety of question formats including situational questions based on past behavior;

- individual answers rated with a predetermined scale and

- $\quad$ presence of anchor answers;

- trained interviewers.

The predictive nature and usefulness of structured interviews are now recognized in some school districts around the country. Washington DC, for example, revised its selection process in 2009 to include a 30-minute structured interview with a district office administrator as a part of a multi-step system designed to increase the likelihood of hiring high-quality teachers (Jacob, 2016).

Moore's (2017) third element of an effective interview process is the addition of other predictive elements so that decisions are not based solely on paper screening and interviews. Although there are many other elements of teacher selection processes utilized in practice, there is little evidence to link them to the future performance of the individual after he or she is hired. Elements such as demonstration lessons taught by candidates, problem-solving within a writing sample, and professional task simulations are often referred to as predictive hiring approaches (Maynes \& Hatt, 2013), but in essence, they are actually subjective measures utilized to determine if a candidate is a fit for a specific school culture (Pappano, 2011) rather than predictive elements linked to future success as a teacher. Similarly, there is not yet a strong research base for commercially available teacher selection tools such as screening assessments. Metzger \& Wu (2008) synthesized 24 studies regarding teacher selection instruments widely used at the time and that the only tool that had a modest relationship $(\mathrm{r}=.28)$ to teaching quality was Gallup's Teacher Perceiver Interview (TPI).

\subsection{Research Questions}

In the end, virtually all classrooms do end up with a teacher, but the quality of that teacher may not be sufficient to ensure appropriate student growth. Given the difficulty that principals may face as they seek to hire qualified candidates and the potential that effective teacher hiring processes may positively impact student outcomes, this study was designed to examine the actual hiring processes utilized in schools located in urban, rural and suburban communities in order to determine the extent to which differences exist based on the location 
of the school and whether those difference are likely to impact teacher quality. Research questions for this study:

RQ1. How do teacher application and screening processes differ in rural, urban, and suburban school communities?

RQ2. What elements are included in hiring processes in rural, urban, and suburban schools, and do they reflect recommendations from recent research, including structured interviews and predictive screening measures?

RQ3. What criteria are used in rural, urban, and suburban schools to determine the successful candidate who is offered a teaching position?

RQ4. What type of teacher selection training is offered to principals in rural, urban, and suburban schools?

\section{Method}

\subsection{Participants}

A link to an electronic survey on the Qualtrics platform was emailed to principals in five states in the southern region and five states in the western region of the United States for two months in the spring of 2018. Email addresses were gathered from publically available documents published by state departments of education. In most cases, the e-mail lists were assembled by these agencies at the beginning of the school year, and by spring there were personnel changes that caused some of the records to be out of date, resulting in undeliverable e-mails and e-mails delivered to some who were no longer principals. Also, many e-mails were classified as spam and not delivered to inboxes.

In total, 10,367 e-mails were sent to principals in Georgia, Alabama, North Carolina, South Carolina, Arkansas, California, Oregon, Washington, New Mexico, and Utah with 934 returned as undeliverable. Of the 9,433 surveys that were delivered, 1008 surveys were completed, which created a response rate of $9.4 \%$. States were selected for their geographical proximity in the south and west and public availability of e-mail addresses.

Principals were asked to provide demographic information for their schools. Fifty percent of participants indicated that they were located in a rural community, 33\% in a suburban community, and $17 \%$ in an urban community. Forty-five percent reported that their school was located in a county-wide K-12 district, $29 \%$ in a city-wide K-12 district, $13 \%$ in a K-12 unified district serving multiple cities but that does not adhere to county borders, $4 \%$ in a high school only district, and 8\% in an elementary school only district.

\subsection{Instrumentation}

The survey questions were written based on the research questions of this study as well as an extensive review of existing research on the topics of teacher quality, teacher selection processes, and best practices in employee selection processes. Survey and question 
construction was guided by Cresswell \& Cresswell (2018). Researchers e-mailed a pilot survey to twenty volunteer participants who were either current or former principals. Revisions were made based on feedback and suggestion of those who participated in the pilot. Data were self-reported, but bias is limited due to anonymous participation of principals with no stake in the outcome and nothing to gain or lose by reporting various types of data. The survey included 42 multiple choice type questions, which requested information on the demographics of the school and the process used to hire teachers. A total of 12 survey questions were directly related to this study.

Several questions sought information about the application and screening process for teacher candidates in rural, urban, and suburban schools. The first question in this category asked, "What elements do you require that a candidate to submit to apply for a teaching position in your school?" Principals selected all that applied from a list that included, "written job application, submitted online," "written job application, submitted as a hard copy," "resume or CV," "letters of reference," "transcripts," "personal statement or statement of teaching philosophy," "copies of credentials," and "portfolio, written or virtual." The second question asked was, "Who reviews application materials and selects candidates to be interviewed?" Principals selected the option that best described their process from a list that included, "principal," "team of school leaders including principal and assistant principal," "assistant superintendent or district office administrator," "school team including teachers and administrators," "team including school and district administrators," and "other."

The next block of questions asked about elements of the interview process to determine if research-based hiring practices were utilized in schools located in rural, urban, and suburban communities. Principals were asked, "Who typically participates in a candidate's first interview?" Participants checked all that applied from the following choices: "principal," "assistant principal," "department chairs or grade level lead," "teachers," "superintendent," "district level personnel director," "district-level curriculum director," "students," and "parents or community members." Participants then answered four questions to determine if elements of structured interviews were utilized. The first question was, "What portion of the interview questions are developed before the first interview?" Answers choices were "all of the questions," "some of the questions," and "none of the questions." The second question asked, "During the interview, how often are identical questions asked of those being interviewed for the position?" Answer choices were "always," "about half the time," "sometimes," and "never." Principals also responded to the question, "Are interview questions designed to identify teacher qualities that are known through research to be predictive of high performance?" Answer choices were "yes," "no," and "not sure." The final question was designed to determine the presence of research-based structured interview elements was, "Do interviews result in measurable data?" Answer choices were "yes," "no," and "not sure."

Principals were asked three questions in order to assess how hiring decisions were made and whether those decisions were based on the qualities of effective teachers as defined by current research. The first question in this section was, "Following the first interview, who decides to move a candidate to the next step of the process?" Answer choices were 
"principal," "principal and assistant principal," "school team including teachers and administrators," "team including school and district level administrators," and "teachers without administrator input." Participants were also asked, "How involved are each of the following in the decision to offer a candidate a teaching job?" Principals used a rating scale of "very involved," "somewhat involved," and "not involved" to rate the level of participation of the superintendent, assistant superintendent, principal, assistant principals, teacher leaders or department heads, teachers, parents, students, and school board members. Principals also responded to the question, "How important are each of the factors below in the final selection of which candidate is offered a teaching position?" Principals rated the importance of the categories of "experience," "reference letters or calls," "content knowledge," "certification," "research-based screening assessment," "ability to collaborate with colleagues," "ability to build relationships with students," "performance on a sample lesson," "ability to ensure student growth," "research-based qualities known to be predictive of high performance as a teacher," and "measurable data gathered from predictive interviews."

Two survey questions were designed to elicit an understanding of participants' experience with teacher selection training. The first question was, "What type of training have you received regarding the selection of high-quality teachers?" Answer choices were "my district provides regular training on research-based selection methods," "I have been trained to administer predictive interviews that generate measurable data," "teacher selection was covered in a graduate or leadership certificate program," "I have attended workshops or conferences about personnel selection," and "none." Finally, principals were asked, "Do you feel that you would benefit from additional training regarding the selection of highly effective teachers?" Answer choices were "definitely yes," "probably yes," "might or might not," "probably not," and "definitely not."

\subsection{Analysis}

Survey results were analyzed in three steps. The first step of the analysis was performed using Qualtrics software to generate the frequency of responses and valid percentages for each of the survey questions as cross-tabulated by rural, urban, and suburban schools. The second step of analysis using the chi-squared test of homogeneity was performed for each question or response that resulted in inconsistent percentages of responses from rural, urban, and suburban respondents in order to determine if the differences were significant. The chi-squared test of homogeneity was chosen because of its ability to determine if a difference exists between the binomial proportions of three independent groups on a dichotomous dependent variable. The five assumptions necessary for the chi-squared test were met: dichotomous dependent variable; three or more categorical, independent groups; independence of observations; retrospective purposive sampling; and sufficient sample size. The third step of analysis took place in instances where a statistically significant difference in proportions between groups was found. Multiple z-tests of two proportions were run for each possible pairwise combination with a Bonferroni adjustment in order to determine between which groups significant differences existed. 


\section{Results}

\subsection{Teacher Application Process}

Principals were asked to indicate the elements required from candidates to complete an application for a teaching position. Table 1 provides the frequency and percentages of responses tabulated by community type.

Table 1. Elements required for application by type of community

\begin{tabular}{lccccccccc}
\hline & Written & & & & & & \\
& Application & Written Application & Resume or & Letters of & Transcripts & Cover & Personal & Credentials & Portfolio \\
\cline { 2 - 8 } & On-line & Hard Copy & CV & Reference & & Letter & Statement & \\
\hline \multirow{2}{*}{ Urban } & 113 & 9 & 109 & 103 & 74 & 91 & 32 & 83 & 11 \\
& $94.17 \%$ & $7.50 \%$ & $90.83 \%$ & $85.83 \%$ & $61.67 \%$ & $75.83 \%$ & $26.67 \%$ & $69.17 \%$ & $9.17 \%$ \\
\multirow{2}{*}{ Suburban } & 242 & 5 & 221 & 158 & 157 & 48 & 48 & 144 & 11 \\
& $97.58 \%$ & $2.02 \%$ & $89.11 \%$ & $85.08 \%$ & $63.71 \%$ & $63.31 \%$ & $19.35 \%$ & $58.06 \%$ & $4.44 \%$ \\
\hline \multirow{2}{*}{ Rural } & 335 & 65 & 310 & 279 & 228 & 234 & 96 & 203 & 17 \\
& $89.57 \%$ & $17.38 \%$ & $82.89 \%$ & $74.60 \%$ & $61.99 \%$ & $62.57 \%$ & $25.67 \%$ & $54.28 \%$ & $4.55 \%$ \\
\hline
\end{tabular}

Analysis of results indicated four areas of difference among schools in rural, urban, and suburban communities. While most schools required a written job application, submitted online, rural schools were most likely to require a written job application submitted as a hard copy. Of the 776 respondents who answered the question regarding the application process, 65 rural school principals (16.8\%), five urban school principals (3.9\%), and nine suburban school principals $(3.5 \%)$ required candidates to complete hard copy applications, a statistically significant difference in proportions $p<.001$. Post hoc analysis involved pairwise comparisons using the z-test of two proportions with a Bonferroni correction. The proportion of rural principals who reported the use of paper applications was significantly higher than either urban or suburban schools, $p<.05$ but the proportion of urban and suburban principals who reported the use of paper applications was not statistically significantly different, $p>.05$.

The second area of difference was found in the requirement for a cover letter as a component of the application process. Two hundred and thirty-four rural principals (60.3\%), 91 urban principals $(71.1 \%)$, and 48 suburban principals (18.5\%) required a cover letter, a statistically significant difference in proportions $p<.001$. Post hoc analysis of pairwise comparisons using the z-test of two proportions with a Bonferroni correction revealed that the proportion of suburban principals who reported cover letters as a required component of the application was significantly lower than either rural or urban schools, $p<.05$; however, the proportion of rural and urban principals who reported the cover letter requirement was not statistically significantly different, $p>.05$.

Requiring copies of teaching credentials as a part of the application also varied by community. Two hundred three rural principals $(52.3 \%), 83$ urban principals $(64.8 \%)$, and 144 suburban 
principals (55.4\%) reported the requirement for teaching credentials to be submitted with applications, a statistically significant difference in proportions of $p=.047$. Post hoc analysis of pairwise comparisons using the z-test of two proportions with a Bonferroni correction found that the proportion of rural principals who reported that credentials be submitted with applications was significantly higher than in urban schools, $p<.05$ and the proportion of rural and suburban principals and the proportion of urban and suburban principals who reported the credential requirement were not statistically significantly different, $p>.05$.

The final area of difference in the teacher application process was found in the requirement for letters of reference where 279 rural principals (71.9\%), 103 urban principals (80.5\%), and 158 suburban principals $(60.8 \%)$ required letters of reference, a statistically significant difference in proportions $p<.001$. Post hoc analysis of pairwise comparisons using the z-test of two proportions with a Bonferroni correction revealed that the proportion of suburban principals who reported that reference letters were required in the application was significantly lower than either rural or urban schools, $p<.05$. The proportion of rural and urban principals who reported the use of the requirement of reference letters was not statistically significantly different, $p>.05$.

\subsection{Teacher Candidate Screening}

Reviewing applications to determine candidates selected for further consideration is typically the first step to narrow the field in an employee selection process. Principals were asked, "Who reviews application materials and selects the candidates to be interviewed?" to gather information about screening. Table 2 presents the frequency and percentages of responses tabulated by community type. In most cases, the screening decisions were made at the school level by the principal alone or in collaboration with the assistant principal. No statistically significant differences were found among districts on this question. The majority of principals in all types of communities indicated that these decisions were made by a team, including the principal and teachers.

Table 2. Personnel responsible for the review of the application and selection of candidates to interview

\begin{tabular}{lccccc}
\hline & Principal & Leadership Team - & Asst. Sup or & School Team - & Team - School \\
\cline { 2 - 6 } & \multicolumn{2}{c}{ Principal \& Asst. Principal } & DO Admin & Teachers \& Admin & \& District Admin \\
\hline Urban & 39 & 33 & 11 & 20 & 13 \\
& $31.97 \%$ & $27.05 \%$ & $9.02 \%$ & $16.39 \%$ & $10.66 \%$ \\
Suburban & 89 & 73 & 18 & 44 & 16 \\
& $35.74 \%$ & $29.32 \%$ & $7.23 \%$ & $17.67 \%$ & $6.43 \%$ \\
Rural & 140 & 102 & 31 & 55 & 43 \\
& $37.43 \%$ & $27.27 \%$ & $8.29 \%$ & $14.71 \%$ & $11.50 \%$ \\
\hline
\end{tabular}




\subsection{Teacher Selection Process}

In order to determine differences in the teacher selection process by type of community, principals responded to questions regarding the personnel involved in teacher selection and the specific elements of the processes.

\subsubsection{Participants in First Interviews}

While the principal is the most likely to be included in the first interview in schools located in rural, urban, and suburban communities, there were differences in the level of involvement of other personnel. Of the 776 participants who responded to this question, 172 rural principals (44.3\%), 67 urban principals (52.3\%), and 165 suburban principals (63.5\%) indicated that they included the assistant principal in first interviews with teacher candidates, a statistically significant difference of proportions $p<.001$. Post hoc analysis involved pairwise comparisons using the z-test of two proportions with a Bonferroni correction. The proportion of rural principals who reported that the participation of assistant principals was significantly lower than in suburban schools, $p<.05$. However, the proportion of rural and urban principals and the proportion of urban and suburban principals who reported that assistant principals participate in first interviews were not statistically significantly different, $p>.05$.

Differences were also found in the level of involvement of the superintendent in first interviews. Twenty-nine rural principals (7.5\%), five urban principals $(3.9 \%)$, and seven suburban principals $(2.7 \%)$ indicated that the superintendent participated in first interviews, a statistically significant difference of proportions $p=.021$. Again, post hoc analysis involved pairwise comparisons using the z-test of two proportions with a Bonferroni correction. The proportion of rural principals who reported superintendent participation in the first interview was significantly higher than either urban or suburban schools, $p<.05$. The proportion of urban and suburban principals who reported superintendent participation in the first interview was not statistically significantly different, $p>.05$.

Finally, chi-square analysis revealed that there was a difference among communities in the involvement of lead teachers in first interviews. One hundred and forty-four rural principals (37.1\%), 51 urban principals (39.8\%), and 132 suburban principals (50.8\%) reported that lead teachers participated in first interviews, a statistically significant difference in proportion $p$ $=.002$. Pairwise z-tests with a Bonferroni correction indicated that the proportion of rural principals who reported the participation of lead teachers was significantly lower than in suburban schools, $p<.05$. However, the proportion of rural and urban principals and the proportion of urban and suburban principals who reported that lead teachers participate in first interviews were not statistically significantly different, $p>.05$.

\subsubsection{Persons Responsible for Decision to Move Candidates to Second Interview}

There were no significant differences in responses among urban, suburban, and rural schools on the question that asked who is responsible for deciding to move a candidate the subsequent steps in the hiring process after the first interview. These decisions are most commonly made by a team of teachers and administrators in all types of schools. 


\subsubsection{Structure of Interviews}

The structures of interview processes were similar in schools in urban, suburban, and rural communities, and analysis proved no significant differences. Eighty-one percent of all principals surveyed reported that interview questions were developed prior to the first interview, $87 \%$ of all surveyed principals indicated that identical questions were asked of all candidates, and $70 \%$ of principals believed that their interview questions were designed to identify teacher qualities that are known through research to be predictive of high performance. Only $43 \%$ of principals reported that interviews resulted in measurable data, and $21 \%$ were unsure.

\subsubsection{Persons Involved in Decisions to Offer Teaching Positions}

To determine how decisions were made to offer teaching positions to candidates, participants were asked to rate the level of involvement of a variety of personnel. Table 3 indicates the percentage of principals who reported "very involved" and "somewhat involved" for each of the persons or groups.

Table 3. Personnel reported as "very involved" or "somewhat involved" in the decision to offer a teaching job

\begin{tabular}{lcccccc}
\hline & Superintendent & Asst. & Principal & Asst. & Teachers & School \\
\cline { 2 - 6 } & & Superintendent & & Principal & & Board \\
\hline Urban & 22 & 23 & 108 & 87 & 92 & 21 \\
& $21.35 \%$ & $22.55 \%$ & $99.08 \%$ & $86.14 \%$ & $90.20 \%$ & $20.79 \%$ \\
Suburban & 56 & 81 & 223 & 199 & 200 & 31 \\
& $33.73 \%$ & $37.67 \%$ & $99.55 \%$ & $88.84 \%$ & $90.10 \%$ & $14.55 \%$ \\
Rural & 179 & 117 & 326 & 218 & 255 & 88 \\
& $55.41 \%$ & $39.53 \%$ & $99.39 \%$ & $73.90 \%$ & $81.21 \%$ & $28.30 \%$ \\
\hline
\end{tabular}

In all types of schools, the principal was very likely to be involved in the decision to hire a teacher but the extent to which the superintendent, school board, assistant superintendents, assistant principals, and teachers were involved varied by type of community. Of the 776 participants who responded to this question, 179 rural principals (46.1\%), 22 urban principals $(17.2 \%)$, and 56 suburban principals $(21.5 \%)$ reported that the superintendent was involved in teacher hiring decisions, a statistically significant difference of proportions $p<.001$. Post hoc analysis of pairwise comparisons using the z-test of two proportions with a Bonferroni correction revealed that the proportion of rural principals who reported the involvement of the superintendent in teacher hiring decisions was significantly higher than either urban or suburban schools, $p<.05$. The proportion of urban and suburban principal responses were not statistically significantly different, $p>.05$.

Similarly, 88 rural (22.7\%), 21 urban (8.1\%), and 31 suburban principals (11.9\%) indicated that the school board participated in teacher hiring decisions, a statistically significant 
difference of proportions $p<.001$. Post hoc analysis of pairwise comparisons using the z-test of two proportions with a Bonferroni correction found that the proportion of rural principals who reported the involvement of the school board in teacher hiring decisions was significantly higher than either urban or suburban schools, $p<.05$. The proportion of urban and suburban principal responses were not statistically significantly different, $p>.05$.

The assistant superintendent was involved in teacher hiring decisions in 117 rural schools (30.2\%), 23 urban schools (18\%), and 81 suburban schools (31.2\%), a statistically significant difference of proportions $p=.015$. Post hoc analysis of pairwise comparisons using the z-test of two proportions with a Bonferroni correction found that the proportion of rural principals who reported the involvement of the assistant superintendents in hiring decisions in urban schools was significantly lower than either rural or suburban schools, $p<.05$. The proportion of rural and suburban principals who reported board involvement in teacher hiring decisions was not statistically significantly different, $p>.05$.

The involvement of Assistant principals in teacher hiring decisions also differs by the community. One hundred and ninety-nine suburban principals $(76.5 \%), 218$ rural principals (56.2\%), and 87 urban principals (46.8\%) reported that the assistant principal was involved in the decision about which teachers to hire, a statistically significant difference in proportions of $p<.001$. Post hoc analysis of pairwise comparison using the z-test of two proportions with a Bonferroni correction revealed that all pairwise comparisons were statistically significant.

The analysis found that teachers are least likely to be involved in new teacher hiring decisions in rural communities. Two hundred fifty-five rural principals (65.7\%), 92 urban principals (71.9\%) and 200 suburban principals (76.9\%) reported that teachers are involved in the decision to hire a teacher candidate, a statistically significant difference in proportions of $p=.009$. Post hoc analysis of pairwise comparisons using the z-test of two proportions with a Bonferroni correction found the proportion of rural principals who reported participation of teachers in teacher hiring decisions was significantly lower than suburban schools, $p<.05$. The proportions of rural and urban and urban and suburban who reported assistant superintendent was not statistically significantly different, $p>.05$.

\subsubsection{Criteria for Decision Making}

To determine if candidates were offered teaching positions based on criteria supported by research, principals rated the importance of a variety of factors in their decision-making process. Table 4 indicates the frequency and percentages of principals who rated each factor as "extremely important." 
Table 4. Criteria used to determine successful teaching candidate rated as "extremely important"

\begin{tabular}{|c|c|c|c|c|c|c|c|c|c|c|}
\hline & Experience & Reference & Content & Certification & Research-Based & Collaborate & Build Student & Ensure & Research-Based & Predictive \\
\hline & & & Knowledge & & Assessment & Colleagues & Relationships & Student Growth & Qualities & Interview \\
\hline \multirow[t]{2}{*}{ Urban } & 32 & 60 & 55 & 75 & 6 & 62 & 84 & 42 & 30 & 20 \\
\hline & $29.36 \%$ & $55.05 \%$ & $50 \% \%$ & $69.44 \%$ & $5.61 \%$ & $56.88 \%$ & $76.36 \%$ & $38.53 \%$ & $27.52 \%$ & $18.69 \%$ \\
\hline \multirow[t]{2}{*}{ Suburban } & 48 & 105 & 87 & 142 & 13 & 143 & 172 & 88 & $56 \%$ & 18 \\
\hline & $21.62 \%$ & $47.30 \%$ & $39.55 \%$ & $64.25 \%$ & $5.94 \%$ & $64.41 \%$ & $77.48 \%$ & $39.82 \%$ & 25.57 & $8.18 \%$ \\
\hline \multirow[t]{2}{*}{ Rural } & 59 & 152 & 137 & 201 & 18 & 162 & 231 & 111 & 66 & 35 \\
\hline & $17.99 \%$ & $46.48 \%$ & $41.52 \%$ & $61.09 \%$ & $5.59 \%$ & $49.39 \%$ & $70.00 \%$ & $33.53 \%$ & $20.18 \%$ & $10.94 \%$ \\
\hline
\end{tabular}

In all types of communities, principals rated the ability to build relationships and teacher certification as essential qualities in their teacher hiring decisions. Principals' rating of the ability to collaborate with colleagues varied by community type with 162 rural $(41.8 \%), 62$ urban (48.4\%), and 143 suburban principals (55\%) reporting it as extremely important, a statistically significant difference of $p=.004$. Post hoc analysis that involved pairwise comparisons using the z-test of two proportions with a Bonferroni correction found the proportion of rural principals who rated collaboration skill as extremely important was significantly higher than in suburban schools, $p<.05$. However, the proportion of rural and urban principals who reported that collaboration skills were extremely important were not statistically significantly different, $p>.05$.

The importance of experience also differed by the community with 59 rural $(15.2 \%), 32$ urban $(25 \%)$, and 48 suburban principals $(18.5 \%)$ who categorized it as extremely important, a statistically significant difference of $p=.042$. Post hoc analysis of pairwise comparisons using the z-test of two proportions with a Bonferroni correction revealed the proportion of rural principals who reported that experience was "extremely important" in their teacher hiring decisions were significantly lower than either urban or suburban schools, $p<.05$. The proportion of urban and suburban principals who reported that experience was not extremely important was not statistically significantly different, $p>.05$.

In all types of communities, it was notable that any response that included "research-based" or "measurable criteria" was not among the most often selected as extremely important. Similarly, the use of predictive interviews was not among the most often selected as extremely important, but there were differences in its importance across communities. Thirty-five rural (9\%), 20 urban (17.7\%), and 18 suburban principals $(6.9 \%)$ indicated that results from predictive interviews were extremely important in their decision to hire a teacher, a statistically significant difference of $p=.004$. Post hoc analysis of pairwise comparisons using the z-test of two proportions with a Bonferroni correction found the proportion of urban principals who rated predictive interviews as extremely important was significantly higher than either rural or suburban schools, $p<.05$. The proportion of rural and suburban principals who categorized predictive interviews as extremely important was not statistically significantly different, $p>.05$. 


\subsection{Teacher Selection Training}

Principals responded to questions designed to elicit an understanding of participants' experience with teacher selection training. In response, $43 \%$ of principals indicated they had received training from a workshop or conference, and $40 \%$ had received training in a graduate course. Only $20 \%$ stated that they had been trained to administer predictive interviews, which result in measurable data, and $24 \%$ of principals indicated that they had not ever been trained in teacher selection. Interestingly, $99 \%$ of principals were at least moderately confident in their ability to select high-quality teachers, and $92 \%$ of principals indicated that they could benefit from further training. There were no significant differences among community types on questions regarding training.

\section{Discussion}

Analysis of the results indicated that while rural, urban, and suburban schools have many similarities in teacher application, screening, hiring processes, and selection criteria, differences do exist in some areas. The analysis also indicated that the majority of principals of schools in all types of communities are not using research-based selection processes that are likely to result in the hiring of more effective teachers who can create the highest levels of student growth. Furthermore, principals in all types of communities reported that personnel selection training most often occurs in graduate courses or workshops and that they believe they can benefit from additional training.

\subsection{Teacher Application Process}

Schools located in rural communities are most likely to require an applicant to fill out a paper, rather than online, application. Paper applications may prove problematic in recruiting candidates who do not reside near the school and Generation Y candidates. Generation Y candidates are also known as millennials, are the first generation of digital natives and expect that potential employers will not only request applications in an online format, but that communication regarding that application will take place electronically (Foltz, 2010). Generation $Y$ teacher candidates may be less likely to engage in a process that requires a hard copy application, thus reducing the potential number of candidates from which a principal has to choose. The impact of organizational attractiveness on potential candidates has been shown to increase the number of qualified candidates in the business field, and this finding likely has implications for educators. When there is competition for relatively few qualified candidates, the organizations that candidates perceive as attractive through the ease of application and ease of information gathering through the organization's website have a competitive advantage (Smither, Reilly, Millsap, \& Stoffey, 1993).

Given that millennials also value teamwork, personal productivity, fulfilling work, and social justice (Meister \& Willyerd, 2010), rural districts may find them to be a good match for their needs. On-line application systems may also enhance the quality of the screening process through the ability of the system to sort candidates based on desired criteria. A lack of access to online applications may exacerbate the problem of over hiring from personal referrals, 
which can result in a subjective process and poor fit (Frontline, 2018).

Rural schools were more likely to request copies of credentials than urban schools, although there was no statistical difference between rural and suburban schools. This finding implies that rural school principals consider whether a candidate holds a valid teaching certificate as they are screening candidates. This finding is somewhat interesting, given that between $60 \%$ $70 \%$ of principals indicated that holding a valid teaching certificate was an extremely important factor when determining which teacher candidate to hire. While holding a valid teaching certificate is not positively correlated with high-quality teaching (Hanna \& Gimbert, 2011). It is nonetheless, a requirement of state laws.

Items that supplement the application were commonly required elements of the application process for all types of schools, but cover letters and letters of reference were less likely to be required by suburban schools than urban or rural schools. Further research is needed to determine why suburban principals require less documentation as a part of the application process than their counterparts in urban and rural schools, but one may hypothesize that principals believe that less required documentation will decrease the burden of the application process for either themselves or the candidates. Further research is also warranted to determine if access to less information at the screening level impacts the number of applicants or quality of screening decisions.

\subsection{Teacher Screening Process}

In most cases, results indicated that the principal made decisions about which candidates to interview alone or in collaboration with the assistant principal. Less often, decisions were made by a district office administrator or in partnership with a district office administrator. These findings were consistent with the current body of literature that indicates that the principal typically fully manages most hiring processes at the school level. No significant difference among types of communities was found in the question regarding the application screening process.

\subsection{Teacher Selection Process}

The questions regarding the teacher selection process were grouped into four categories: personnel who participate in the interview process, the presence of elements of structure in interviews, desired characteristics of teachers, and personnel who make hiring decisions. The personnel who participate in teacher interviews does vary by the type of district. The principal is most likely to be involved in the interview process in all types of schools, but the statistical analysis found that rural schools are less likely than suburban schools to also include an assistant principal or lead teacher in the first interview. The exclusion of assistant principals and lead teachers, who are often aspiring principals, may be a lost opportunity for personnel selection training. Conversely, rural schools were more likely than urban and suburban schools to include the superintendent in the first interview with a teacher. Further research is necessary to determine if this phenomenon is due to a lack of other available personnel because of small school sizes or higher levels of superintendent oversight.

In schools in all types of communities, teachers were more likely than not to participate in 


\section{Mll Macrothink}

International Journal of Education

ISSN 1948-5476

2019, Vol. 11, No. 3

first interviews, which indicates the popularity of unstructured panel interviews. Given the prevalence of schools that include teachers in first interviews, it follows suit that the most utilized method of determining candidates to move to the next steps of the selection process was a collaborative decision by teachers and school-level administrators. In about a quarter of the schools, the principal makes the decision alone, which would be appropriate if the interview were indeed structured and resulted in valid and reliable measurable data. This finding also supports the literature that many teacher hiring systems are extremely de-centralized with principals who responsible for hiring.

Some of the basic elements of structured interviews were commonly used in all types of districts. A majority of principals indicated that they prepared questions ahead of time, and asked the same questions of each candidate. They also believed their questions were designed to identify teacher qualities that are known through research to be predictive of high performance. The results changed when principals were asked if their interviews generated measurable data. Less than half of principals reported that interviews resulted in quantifiable data, and about $20 \%$ were unsure. It is not likely that those who are uncertain are collecting data that is quantifiable.

Principals of schools located in all types of communities indicated that principals and assistant principals were likely to be "very involved" or "somewhat involved" in the decision to offer a candidate a teaching position. Although suburban schools were also significantly more likely to include assistant principals in teacher hiring decisions than in rural and urban schools. The majority of principals also indicated that teachers were highly involved in hiring decisions, but rural schools were significantly less likely than their suburban counterparts to involve teachers. This issue may result in a lost opportunity for collaboration and to train others in selection processes. Rural school principals reported they were significantly more likely to involve the superintendent and school board in teacher hiring decisions than in suburban and urban settings. Further research is needed to determine the reasons for the inclusion of these non-traditional participants in teacher hiring. Finally, urban principals reported that they were significantly less likely than suburban and rural districts to include an assistant superintendent in hiring decisions, which may be due to the large size of many urban districts.

Survey results indicated that principals aligned their hiring decisions to some, but not all of the qualities that research would indicate are predictive of teacher success. Teacher quality literature supports both building relationships with students and collaboration with colleagues as essential skills (Hattie \& Zierer, 2018; Schmidt, 2018). The ability to build relationships with students was rated as extremely important to principals in all types of communities without significant differences. The importance of the ability of the candidate to collaborate with colleagues was relatively important to all principals, but rural principals rated it as extremely important significantly less often than suburban principals. Given that collaboration with colleagues is one of the most often cited qualities of effective teachers, this difference in rural schools could impact the quality of teachers hired and ultimately, student outcomes. 
Principals in all types of schools also rated experience and certification as important in their hiring decisions. Research has found that while possessing a teacher is a typical requirement of state departments of education and districts; it is not indicative of high teacher quality (Hanna \& Gimbert, 2011). Experience, which is supported by research as one of the only consistently predictive factors for teacher success, was not rated as extremely important as often as experience by principals in all types of communities. Furthermore, rural principals rated experience as "extremely important" significantly less often than urban principals. Again, this factor could impact the quality of the teachers who are hired.

The ability to ensure student growth, which is the overall purpose of instruction and indicative of teachers who understand their impact, was not among the most often rated as "extremely important" to principals in all types of communities. Finally, the criterion that mentioned "research" and "measurable data" were among the lowest rated by all principals although urban principals expressed that they were significantly more likely to value the outcomes of predictive structured interviews than rural or suburban principals. The lack of use of research-based hiring methods, the use of measurable data, and predictive interviews are lost opportunities for principals to ensure that they are hiring the best possible teachers.

\subsection{Teacher Selection Training}

While there were no significant differences among schools in rural, urban, and suburban settings regarding teacher selection training of principals, about a quarter of all principals indicated that they had not ever received training in selection methods. Of those who did note that they had received training, $43 \%$ reported that they received instruction in a workshop or conference and $40 \%$ in a graduate course. Only $20 \%$ indicated that they had been trained to administer predictive interviews, which result in measurable data. This result creates a discrepancy in the data, given that earlier in the survey, $70 \%$ of principals indicated their belief that the interview questions they utilized were designed to identify teacher qualities that are known through research to be predictive of high performance and $43 \%$ of principals reported that their interviews resulted in measurable data. These results suggest that there may be a disconnect between principals' beliefs about the effectiveness of their selection processes and reality. This disconnect is seen again in questions regarding confidence and the need for further training. When asked, "How confident are you in your ability to select high-quality teachers who can ensure high levels of student growth?", 99\% of principals were at least moderately confident in their ability.

In contrast, $92 \%$ of principals indicated that they would benefit from further training. This level of confidence is entirely consistent with almost 100 years of research about the lack of validity and reliability, yet consistent popularity of interviews with those who make hiring decisions (Buckley, Norris, \& Wiese, 2000). Employers favor interviews as a hiring method even though it is commonly known that impressions of candidates are formed quickly and then interviewers tend to listen for responses that confirm these impressions rather than ask questions that may disprove their initial thoughts (Dana, Dawes, \& Peterson, 2013). The natural tendency of an interviewer to hear what confirms his or her beliefs may lead to a false sense of confidence in the process. 


\section{Conclusion}

\subsection{Limitations}

The distribution method of the survey may create a potential limitation for this study. Surveys were sent via e-mail to principals in a total of ten states in the southern and western regions of the United States. Principals in the other areas of the country may have different experiences and opinions not represented in this data set, and therefore, results may not be generalizable to the entire USA. Also, distributing a survey via e-mail creates a situation in which not all intended participants had the opportunity to take the survey because of e-mail blocked as spam and personnel changes from the time of e-mail list development to actual distribution. By nature, surveys garner self-reported data, which may create another potential limitation for this study. Anonymous survey data was taken at face value and cannot be independently verified.

\subsection{Implications}

The results of this study suggest that although the process to hire teachers is primarily driven by principals, there are differences among urban, suburban, and rural schools in terms of the elements in the process, the personnel who participate and who make decisions, and teacher characteristics that drive the ultimate hiring decisions. It is clear from the literature that rural and urban school principals face barriers in hiring that suburban principals do not. The extent to which teacher shortages faced by rural and urban districts impact their hiring process is a subject of ongoing research. In all types of districts, there is a need for both further studies of why structured interviews that would significantly increase the validity of the interview process are not more commonly utilized beyond the incorporation of the most basic element of identical questions for each candidate. Further study is also needed to determine why interview questions are not more commonly aligned to the qualities of effective teachers identified by research. There is also a need for more training for all principals, but especially those in rural settings, to implement selection processes more closely aligned to research and therefore, more likely to identify the teachers most likely to impact student growth positively.

\section{References}

Ballard, K., \& Bates, A. (2008). Making a Connection between Student Achievement, Teacher Accountability, and Quality Classroom Instruction. The Qualitative Report, 13(4), 560-580.

Barnum, M. (2017). 3 big problems in how schools hire teachers and what research says about how to solve them. The 74 Million. Retrieved from https://www.the 74million.org/article/3-big-problems-in-how-districts-hire-teachers-andways-to-solve-them/

Behrstock, E., \& Coggshall, J. G. (2009). Key issue: Teacher hiring, placement, and assignment practices. National Comprehensive Center for Teacher Quality. Retrieved from https://eric.ed.gov/contentdelivery/servlet/ERICServlet?accno=ED543675 
Bourke, K. B. (2012). Public secondary school principals' perspectives on teacher hiring: What matters most? (Doctoral dissertation). Retrieved from http://gateway.proquest.com/openurl?url_ver=Z39.88-2004\&rft_val_fmt=info:ofi/fmt:ke v:mtx:dissertation\&res_dat=xri:pqm\&rft_dat=xri:pqdiss:3548506

Boyd, D., Lankford, H., Loeb, S., \& Wyckoff, J. (2003). The draw of home: How teachers' preferences for proximity disadvantage urban schools. (Working Paper No. 9963) Cambridge: National Bureau of Economic Research. https://doi.org/10.3386/w9953

Buckley, R. M., Norris, A. C., \& Wiese, D. S. (2000). A brief history of the selection interview: May the next 100 years be more fruitful. Journal of Management History, 6(3), 113-126. https://doi.org/10.1108/eum0000000005329

Buddin, R., \& Zamarro, G. (2009). Teacher qualifications and student achievement in urban elementary schools. Santa Monica, CA: Rand Corporation. https://doi.org/10.1016/j.jue.2009.05.001

Cannata, M., Rubin, M., Goldring, E., Grissom, J. A., Neumerski, C. M., Drake, T. A., \& Schuermann, P. (2017). Using teacher effectiveness data for information-rich hiring. Educational Administration Quarterly, 53(2), 180-222. https://doi.org/10.1177/0013161x16681629

Chingos, M. M., \& Peterson, P. E. (2011). It's easier to pick a good teacher than to train one: Familiar and new results on the correlates of teacher effectiveness. Economics of Education Review, 30(3), 449-465. https://doi.org/10.1016/j.econedurev.2010.12.010

Clement, M. C. (2009). Hiring highly qualified teachers begins with quality interviews. Kappan, 9(2), 22-24. https://doi.org/10.1177/003172170909100205

Cresswell, J. W., \& Cresswell, J. D. (2018). Research design: Qualitative, quantitative, and mixed method approaches (5th ed.). Thousand Oaks, CA: Sage Publications.

Crosby, O. (2000). Employment interviewing: Seizing the opportunity and the job. Occupational Outlook Quarterly, 44(2), 14-21.

Dana, J., Dawes, R., \& Peterson, N. (2013). Belief in the unstructured interview: The persistence of an illusion. Judgment and Decision Making, 8(5), 512-520.

Darling-Hammond, L. (2000). Teacher quality and student achievement: A review of state policy evidence. Education Policy Analysis Archives, 8(1). https://doi.org/10.14507/epaa.v8n1.2000

Deli, D. A., \& Vera, E. M. (2003). Psychological and contextual influences on the teacher selection interview: A model for future research. Journal of Personnel Evaluation in Education, 17(2), 137-218. https://doi.org/10.1023/b:peev.0000032425.42878.f3

Engel, M. (2013). Problematic preferences? A mixed-method examination of what principals' preference for teacher characteristics in Chicago. Educational Administration Quarterly, 49, 52-91. https://doi.org/10.1177/0013161x12451025 
Folz, W. L. (2010). Recruiting Generation Y. Educational Leadership, 67(8), 32-33.

Frontline Research \& Learning Institute. (2018). How hiring bias might be compounding the teacher shortage. Retrieved from https://www.frontlineinstitute.com/uploads/2018/01/How_Hiring_Bias_Might_Be_Com pounding_the_Teacher_Shortage_-_Frontline_Research_Learning_Institute.pdf

Hamdni, M. R., Valcea, S., \& Buckly, R. M. (2014). The relentless pursuit of construct validity in the design of employment interviews. Human Resource Management Review, 24(2), 160-176. https://doi.org/10.1016/j.hrmr.2013.07.002

Hanna, P., \& Gimbert, B. (2011). Falling flat: Certification as an insufficient indicator of teacher quality. Journal of the National Association for Alternative Certification, 6(2), $31-52$.

Hanushek, E. A., \& Rivkin, S. G. (2007). Pay, working conditions and teacher quality. The Future of Children, 17(1), 69-86. https://doi.org/10.1353/foc.2007.0002

Harmon, H. L. (2001, March 2). Attracting and retaining teachers in rural areas. Paper presented at the Annual Meeting of the American Association of Colleges for Teacher Education, Dallas, TX. Retrieved from https://eric.ed.gov/contentdelivery/servlet/ERICServlet?accno=ED455081

Hattie, J. (2009). Visible learning: A synthesis of over 800 meta-analyses related to achievement. New York, NY: Routledge. https://doi.org/10.4324/9780203887332

Hattie, J., \& Zierer, K. (2018). 10 Mind frames for visible learning: Teaching for success. New York, NY: Routledge. https://doi.org/10.4324/9781315206387

Jacob, B. A. (2007). The challenges of staffing urban schools with effective teachers. Future of Children, 17(1), 129-153. https://doi.org/10.1353/foc.2007.0005

Jacob, B. A. (2016). The power of teacher selection to improve education. Washington, DC: Brookings Institute.

Jimerson, L. (2003). The competitive disadvantage: Teacher compensation in rural America. Washington, DC: Rural School and Community Trust. Retrieved from http://www.ruraledu.org/docs/Teacher_Pay.pdf.

Konoske-Graf, A., Partelow, L., \& Benner, M. (2016, December 22). To attract great teachers, school districts must improve their human capital systems. Retrieved from https://www.americanprogress.org/issues/education-k-12/reports/2016/12/22/295574/toattract-great-teachers-school-districts-must-improve-their-human-capital-systems/

Lavashina, J., Hartwell, C. J., Morgeson, F. P., \& Campion, M.A. (2014). The structured employment interview: Narrative and quantitative review of the research literature. Personnel Psychology, 67(1), 241-293. https://doi.org/10.1111/peps.12052

Levin, J., \& Quinn, M. (2003). Missed opportunities: How we keep high-quality teachers out of urban classrooms. Baltimore, MD: The New Teacher Project with support from 
Washington Mutual Foundation.

Luft, V. D. (1993). Teacher recruitment and retention practices in rural school districts. Rural Educator, 14(2), 20-24.

Macan, T. (2009). The employment interview: A review of current studies and directions for future research. Human Resource Management Review, 19(3), 203-218. https://doi.org/10.1016/j.hrmr.2009.03.006

Marzano, R. (2003). What works in schools: Translating research into action. Alexandria, VA: ASCD.

Maynes, N., \& Hatt, B. E. (2011). Grounding program change in students' learning: A model for the conceptual shift in thinking that will support valuable program change in response to faculty of education reviews. In T. Falkenberg \& H. Smits (Eds.), The question of evidence in research in teacher education in the context of teacher education program review in Canada (2 vols.). Winnipeg: University of Manitoba, Faculty of Education.

McDaniel, M. A., Schmidt, F. L., \& Hunter, J. E. (1988). A meta-analysis of the validity of methods for rating training and experience in personnel selection. Personnel Psychology, 41(2), 283-309. https://doi.org/10.1111/j.1744-6570.1988.tb02386.x

Meister, J. C., \& Willyerd. K. (2010). Mentoring Millennials. Harvard Business Review, 88(5), 68-72. Retrieved from https://hbr.org/2010/05/mentoring-millennials

Mertz, N. (2010). Teacher selection and school leader effects. Journal of School Leadership, 20(2), 184-207. https://doi.org/10.1177/105268461002000204

Metzger, S. A., \& Wu, M. J. (2008). Commercial teacher selection instruments: The validity of selecting teachers through beliefs, attitudes, and values. Review of Educational Research, 60(4), 921-940. https://doi.org/10.3102/0034654308323035

Monk, D. H. (2007). Recruiting and retaining high-quality teachers in rural areas. Future of Children, 17(1), 155-174. https://doi.org/10.1353/foc.2007.0009

Moore, D. A. (2017). How to improve the accuracy and reduce the cost of personnel selection. California Management Review, 60(1), 8-17. https://doi.org/10.1177/0008125617725288

National Center for Education Statistics (NCES). (2006). Characteristics of schools, districts, teachers, principals, and school libraries in the United States, 2002-04. Report 2006-313. Washington, DC: US Department of Education. Retrieved from https://nces.ed.gov/pubsearch/pubsinfo.asp?pubid=2006313

Nicklin, J. M., \& Roch, S. G. (2009). Letters of recommendation: Controversy and consensus from expert perspectives. International Journal of Selection \& Assessment, 17(1), 76-91. https://doi.org/10.1037/e518572013-338

Organization for Economic Cooperation and Development (OECD). (2004). The quality of the teaching workforce: Policy brief. OECD Observer. Retrieved from 
http://www.oecd.org/dataoecd/17/9/29478720.pdf

Organization for Economic Cooperation and Development (OECD). (2005). Teachers matter: Attracting, developing and retaining effective teachers. Paris: OECD. Retrieved from http://www.oecd.org/education/school/48627229.pdf

Pappano, L. (2011). Using research to predict great teachers. Harvard Education Letter, 27(3).

Pillsbury, P. (2005). Only the best: hiring outstanding teachers. Leadership, 35(2), 36-38.

Rockoff, J. E., Jacob, B. A., Kane, T. J., \& Staiger, D. O. (2011). Can you recognize an effective teacher when you recruit one? Education Finance and Policy, 6(1), 43-74. https://doi.org/10.3386/w14485

Schmid, R. (2018). Pockets of excellence: Teacher beliefs and behaviors that lead to high student achievement at low achieving schools. SAGE Open. https://doi.org/10.1177/2158244018797238

Smither, J. W., Reilly, R. R., Pearlman, K, \& Stoffey, R. W. (1993). Applicant reactions to selection procedures. Personnel Psychology, 46(1), 49-76.

Stone, D. (1990). Recruiting and retaining teachers in rural schools. Knowledge Brief, 4:1-5; Far West Laboratory for Educational Research and Development, San Francisco, CA.

Stronge, J., Ward, T., Tucker, P., \& Hindman, J. (2008). What is the relationship between teacher quality and student achievement? An Exploratory Study. Journal of Personnel Evaluation in Education, 20(3), 165-184. https://doi.org/10.1007/s11092-008-9053-z

Structured Interviews: A practical guide. (2008). Washington, DC: US Office of Personnel Management. Retrieved from https://www.opm.gov/policy-data-oversight/assessment-and-selection/structured-intervie ws/guide.pdf

Teachers matter: Understanding teachers' impact on student achievement. (2012). Santa Monica, CA: RAND Corporation. Retrieved from https://www.rand.org/pubs/corporate_pubs/CP693z1-2012-09.html

Townsell, R. (2007). Human resource management in small rural districts: The administrator's role in recruitment, hiring, and staff development. National Forum of Applied Educational Research Journal, 20(3).

Troutman, L. D. (2012). The impact of principal leadership on school culture and student achievement. (Doctoral dissertation). Retrieved from http://gateway.proquest.com/openurl?url_ver=Z39.88-2004\&rft_val_fmt=info:ofi/fmt:ke v:mtx:dissertation\&res_dat=xri:pqm\&rft_dat=xri:pqdiss:3545656

Wellins, R. S., \& Schweyer, A. (n.d.). Talent management in motion-Keeping up with an evolving workforce. Washington, DC: Human Capital Institute/Development Dimensions International. 
WestED. (2000). Ensuring teacher quality: A continuum of teacher preparation and development policy brief. San Francisco, CA: WestED.

Will, M. (2019, March 19). Taking the guesswork out of teacher hiring. EdWeek, 38(25), $1-13$.

\section{Copyright Disclaimer}

Copyright for this article is retained by the author, with first publication rights granted to the journal.

This is an open-access article distributed under the terms and conditions of the Creative Commons Attribution license (http://creativecommons.org/licenses/by/3.0/). 